ВАСИЛЬЕВ Юрий Альбертович - доктор исторических наук, профессор Московского гуманитарного университета (111395, Россия, г. Москва, ул. Юности, 5; region@тоsgu.ru)

КАСАНОВА ТОРРЕС Агустин Эмилиано (Уругвай, Монтевидео) - аспирант кафедры истории и регионоведения Московского гуманитарного университета (111395, Россия, г. Москва, ул. Юности, 5; region@тоsgu.ru)

\title{
В.О. КЛЮЧЕВСКИЙ КАК ОСНОВОПОЛОЖНИК ЭКОНОМИЧЕСКОЙ ИСТОРИИ РОССИИ
}

\begin{abstract}
Аннотация. В статье В.О. Ключевский утверждается в качестве основателя экономического направления в русской историографии, научной экономической истории в России. Авторы акцентируют внимание на положении, что экономизм Ключевского, в отличие от западной науки, связан не с юридическими формами хозяйства и не с развитием индустрии (как в марксизме), а с бытом и нравственными основами жизни. Обоснован авторский взгляд в отношении синтетического подхода В.О. Ключевского к разработке истории России, основанного на полифакторном методе. Авторы показывают, что данный исследовательский метод заключается не в приоритетности отдельных факторов исторического процесса, а в их взаимодействии.
\end{abstract}

Ключевые слова: история России, теория и методология истории, В.О. Ключевский, экономическая история, экономический материализм, материалистическое понимание истории

B ыдающийся представитель русской исторической школы В.О. Ключевский (1841-1911) осуществил разработку синтетического подхода, основанного на полифакторном методе и использовании достижений общественных наук. Его научный подход актуален и сегодня, однако не востребован в должной мере. По Ключевскому, содержание исторического процесса заключалось не в приоритетности факторов, а в их взаимодействии. Главное проявлялось не в том, вытекал ли политический фактор из экономического или наоборот. Важнее было то, что наступал момент, когда оба ряда факторов начинали действовать вместе, влияя друг на друга; на их взаимодействии созидался общественный порядок, характер которого зависел от вызванных этим взаимодействием новых сочетаний тех и иных факторов. На Руси издавна сложилось органическое единство труда и быта земледельца: они взаимодополнялись, перемежались, создавая своеобразный образ жизни, олицетворяемый понятием «крестьянский двор» [Васильев 1992: 3].

Ключевского современники называли основателем экономического направления в русской историографии, научной экономической истории в России. Исследователь признавал общность исторического процесса в мире, в котором важная роль отводилась экономическим и социальным явлениям. История России определялась как история страны, которая колонизуется. Колонизация (переселение) называлась основным фактом истории страны. В основе колонизации как явления русской истории, по Ключевскому, лежали экономический и хозяйственный факторы.

Обвинения в адрес Ключевского по поводу «эклектических сочетаний» социальных, экономических и политических процессов в истории народа обосновывались утверждением, что перечисленные процессы «оказывались в подчиненном положении» в отношении колонизационного процесса. Критики усматривали якобы теоретический парадокс в концепции Ключевского: колонизационные движения играли профилирующую роль в жизни народа, однако они не определяли социально-экономические явления в историческом процессе [Ключевский 1987: 368]. Однако в концептуальной схеме Ключевского экономические, политические, социальные процессы состав- 
ляли содержание и характер колонизации на территории Русской равнины как комплексного явления, обусловили мотивацию всего колонизационного процесса. Ключевский рассмотрел не только последствия колонизации, но само ее многогранное экономическое, политическое, социальное, культурное содержание. Где же здесь парадокс, если колонизационный процесс можно одновременно рассматривать и как экономическую, и как политическую, и как социальную колонизацию?

Экономическую жизнь в период Руси Днепровской, городовой, торговой, по Ключевскому, определяла внешняя торговля с обусловленными ею лесными промыслами, звероловством и бортничеством. Основу экономической жизни Руси Верхневолжской, удельно-княжеской, вольно-земледельческой, составляла сельскохозяйственная, земледельческая эксплуатация верхневолжских земель посредством вольного крестьянского труда. Основной характеристикой экономической жизни Руси Великой, Московской, царско-боярской, военноземлевладельческой, оставалась сельскохозяйственная разработка прежнего верхневолжского суглинка, а также средневолжского и донского чернозема посредством вольного крестьянского труда. Наконец, в период всероссийский, императорско-дворянский, экономическую жизнь России определял земледельческий труд, окончательно ставший крепостным, который дополняла обрабатывающая, фабричная и заводская промышленность [Ключевский 1987: 51-53].

Идею торгового значения Киева (основную в его исторической схеме) Ключевский мог обнаружить у немецкого исследователя XVIII в. Г. Шторха, который связывал происхождение древнейшей городской и государственной жизни Руси с широким развитием внешней торговли с Константинополем и арабами, но считал эту торговлю транзитной, т.е. чуждой окружающим племенам. Однако постановка экономической темы у Ключевского представлена в органическом, а не только литературном происхождении. Ключевский занимался ее изучением по житиям русских святых и памятникам монастырского хозяйства. Он создал очерк монастырской колонизации Русского Севера, оставшийся в набросках нескольких лекций. Первая экономическая работа Ключевского - о Соловецком монастырском хозяйстве - была напечатана в 1869 г. В это время Ключевский не мог получить вдохновляющий импульс в западной историографии: он опередил расцвет исторического экономизма на Западе, поскольку историко-экономическая школа в Западной Европе (Родбертус, Инама-Штернегг, Роджерс) зародилась только в 1870-х гг. Кроме того, задолго до появления теории протестантской этики Макса Вебера Ключевский выявил религиозно-психологические основы церковно-бытового (православного) хозяйства.

В историографии отмечалось влияние на Ключевского русских предшественников - славянофилов-почвенников: интерес к быту, обрядам и этнографии в хозяйственном быту при изучении русской народности. Отказавшись, однако, в отличие от славянофилов, от идеализации народа, Ключевский рассматривал экономические основания расслоения народа на различные социальные группы, классы. Горизонтальное деление общества по экономическому основанию сочеталось с вертикальным делением общества по сословно-нравственному основанию.

Экономизм Ключевского, в отличие от западной науки, связан не с юридическими формами хозяйства и не с развитием индустрии (как в марксизме), а с бытом и нравственными основами жизни. Как отмечал известный российский экономист и публицист П.Б. Струве, «к числу тех историков XIX века, которые совершенно самостоятельно, по-видимому помимо каких-либо прямых, книжных или идеологических влияний, действием собственного углубленного 
изучения фактов и собственной интуиции, пришли к признанию важности “экономического” фактора в процессе социального развития, принадлежит и В.О. Ключевский. Про свое поколение я смело могу сказать, что экономическому объяснению истории оно училось не только из “Капитала" Маркса, но и из “Боярской думы” Ключевского, где влияние хозяйственных сил и побуждений на социальную эволюцию русского допетровского общества было изображено с такой классической пластичностью, которою никогда не располагал Маркс» [Струве 1952: 332].

По признанию П.Н. Милюкова, понятие экономического материализма не отождествлялось с марксизмом: экономический материализм был в моде на Западе раньше, и независимо от Маркса. Отдельные теоретические сочинения западных специалистов в духе экономического материализма доходили и в Россию (Лориа, Торольд Роджерс), первый том «Капитала» Маркса в переводе Бакунина и во французском сокращенном изложении Малона появились позднее [Милюков 1991: 76].

Материалистическое понимание истории в историческом подходе Ключевского кардинально отличалось от марксистского материалистического монизма. В то же время, по мнению Г.П. Федотова, «если в России исторический марксизм нашел для себя сравнительно благодарную почву, то это потому, что она была подготовлена для него Ключевским. Экономический историзм его, столь жизненный и конкретный, предрасполагал ко всякому экономизму, даже материалистическому. Удача Ключевского вдохновляла на дерзание. Конечно, большинству за это дерзание пришлось заплатить самой дорогой ценой - ценой вульгарности. Но поскольку в революционной России разрабатывается русская история как наука - даже в марксистском освещении, - в ней доживает себя, изуродованная и стиснутая в колодки, школа Ключевского» [Федотов 1991: 346-347].

Первичными условиями экономической жизни русских славян, по Ключевскому, являлись сравнительная медленность их развития и сравнительная простота их общественного состава, а также значительное своеобразие и противоречие этого развития. В XI в. население Руси сосредоточивалось в черноземном Среднем Поднепровье, а к половине XV в. передвинулась в область Верхнего Поволжья. Казалось бы, в первом краю основанием народного хозяйства должно было стать земледелие, а во втором должны были получить преобладание внешняя торговля, лесные и другие промыслы. Но внешние обстоятельства сложились так, что, пока Русь сидела на днепровском черноземе, она преимущественно торговала продуктами лесных и других промыслов и принялась усиленно пахать, когда пересела на верхневолжский суглинок [Ключевский 2003: 12].

В первые века отечественной истории важнейшие реки южной Руси направляли русскую торговлю к черноморским, азовским и волжско-каспийским рынкам, где были востребованы преимущественно мед, воск, меха - продукты леса и в меньшей степени хлеб. Это сделало внешнюю торговлю господствующей силой в народном хозяйстве русских славян и вызвало усиленное развитие лесных промыслов, звероловства и бортничества. Но потом под давлением, шедшим из тех же степей, по которым пролегали пути русской торговли, главная масса русского населения передвинулась в область Верхней Волги. Удаление от приморских рынков ослабило внешний сбыт и сократило лесную промышленность, а это привело к тому, что хлебопашество стало основой народного хозяйства. Получилось, что на открытом днепровском черноземе Русь усиленно эксплуатировала лесные богатства и торговала, а на лесистом верхневолжском суглинке стала усиленно выжигать лес и пахать. 
Внешние международные отношения, влиявшие на размещение населения в стране, переплетались с внутренними географическими ее особенностями в такой запутанный узел, что народный труд, подчиняясь одним условиям, получал направление, не соответствовавшее другим. Древняя Русь выработала свою форму торгового товарищества, в котором соединялись не капиталы, а лица на основе родства и нераздельности имущества. Так, из древнерусского родственного союза под действием экономической потребности выработалась идея торгового дома. Русская равнина своими реками мешала плотному расселению, лесами и болотами затрудняла хозяйствование среди соседей, чуждых по происхождению и низших по развитию, у которых нечего было позаимствовать и с которыми приходилось постоянно бороться [Ключевский 1987: 46, 48].

Связующим элементом в образовании государства служило уже не чувство кровного родства, а экономический интерес, вызванный к действию особенностями территории и внешними обстоятельствами. Южные реки втянули восточных славян в оживленную внешнюю торговлю. Эта торговля соединила разбросанные одинокие дворы в сельские торговые средоточия, погосты, впоследствии - в торговые города с их областями, которые превратились в политические центры, а их торговые округа стали их государственными территориями, городовыми областями. Городовая область стала первой местной политической формой, образовавшейся на Руси в середине IX в. Торговый округ управлялся укрепленным городом, который одновременно служил промышленным центром для данного округа. Большие города как центры городовых областей возникли в тех племенах, которые принимали наиболее активное участие во внешней торговле.

Некоторые из этих областей образовали княжества, а из их соединения образовалось Древнерусское государство. Такова связь экономических и политических фактов в начальной истории Руси: экономические интересы последовательно превращались в общественные связи, из которых вырастали политические союзы. Киев имел общерусское значение как узловой пункт торгово-промышленной деятельности и поэтому стал центром политического объединения всех русских земель. Экономический интерес направлял внешнюю деятельность первых киевских князей, в которой проявились две цели: достижение заморских рынков, обеспечение и охрана торговых путей, которые вели к рынкам. Византийские походы вызывались большей частью стремлением Руси поддерживать или восстановливать торговые отношения с Византией. Поэтому они обычно заканчивались торговыми договорами. Все договоры Руси с Византией Х в. имели торговый характер [Ключевский 1987: 148-150, 161-162, 164, 167 168].

Русская Правда квалифицировалась Ключевским преимущественно как уложение о капитале. Капитал служил предметом особенно напряженного внимания для законодателя: человек рассматривался как орудие капитала. Капитал обусловил важнейшие юридические отношения, которые формулировал закон: по закону строже наказывались деяния, направленные против собственности, чем нарушение личной безопасности. Капитал служил также средством возмездия за преступления и гражданские правонарушения: на нем основана система наказаний и взысканий. Само лицо рассматривается в Русской Правде не столько как член общества, сколько как владелец или производитель капитала. Лицо, его не имеющее, теряло права свободного или полноправного человека [Ключевский 1987: 310].

Экономический фактор, по Ключевскому, оказал существенное влияние на последующее развитие русских земель. В Верхневолжской Руси, удаленной от приморских рынков, внешняя торговля не могла стать главной движущей 
силой народного хозяйства. Данным обстоятельством объясняется сравнительно незначительное число городов в XV-XVI вв. Сельские поселения получили перевес над городами [Ключевский 1987: 310].

Основные положения теории истории, сформулированные В.О. Ключевским, позволяют определить его, наряду с Н.И. Кареевым, как основоположника нового «социологического направления» в исторической науке. Синтетические построения Ключевского позволили воссоздать единство исторического процесса, сформировать целостный взгляд на природу, общество и человека. На основе исторического материала исследователь русской истории поднялся до уровня обобщений, приобретавших философский смысл: в области теории исторического знания был выявлен и осмыслен целый ряд онтологических проблем, в теории исторического процесса - комплекс гносеологических и логических вопросов, в общей схеме социально-исторического процесса - аксиологических и праксиологических аспектов. Решительный поворот, осуществленный Ключевским в исторической науке, нашел отражение в русской общественной мысли в целом.

\section{Список литературы}

Васильев Ю.А. 1992. Деревня на распутье. К возрождению села: формирование условий жкизнедеятельности и культуры быта. М.: Молодая гвардия. $146 \mathrm{c.}$

Ключевский В.О. 1987. Курс русской истории. - Сочинения: В 9 т. М.: Мысль. T. $1.430 \mathrm{c}$.

Ключевский В.О. 2003. Боярская дума древней Руси. - О государственности в России. М.: Мысль. С. 3-448.

Милюков П. Н. 1991. Воспоминания. М.: Политиздат. 528 с.

Струве П.Б. 1952. Социальная и экономическая история России с древнейших времен до нашего времени, в связи с развитием русской культуры и ростом российской государственности. Париж. 386 с.

Федотов Г.П. 1991. Россия Ключевского. - Судьба и грехи России: избранные статьи по философии русской истории и культуры. Т. 1. СПб: София.

VASIL'EV Yuriy Albertovich, Dr.Sci. (Hist.), Professor of the Moscow University for the Humanities (5 Yunosti St, Moscow, Russia, 111395; region@mosgu.ru)

KASANOVA TORRES Agustin Emiliano, postgraduate student at the Chair of History and Regional Studies, Moscow University for the Humanities (5 Yunosti St, Moscow, Russia, 111395; region@mosgu.ru)

\section{O. KLYUCHEVSKY AS THE FOUNDER OF THE ECONOMIC HISTORY OF RUSSIA}

\footnotetext{
Abstract. V.O. Klyuchevsky is approved as the founder of the economic direction in Russian historiography, and scientific economic history in Russia. The paper focused attention on the position that Klyuchevsky's economism, unlike western science, was not associated with legal forms of economy and with the development of industry (as in Marxism), but with everyday life and moral foundations of life. The author's view of V.O. Klyuchevsky' synthetic approach to the development of the history based on the multifactorial method is substantiated. The authors show that this research method did not consist in the priority of individual factors of the historical process (economic, social, political, etc.), but in their interaction.

Keywords: history of Russia, theory and methodology of history, V.O. Klyuchevsky, economic history, economic materialism, materialistic understanding of history
} 